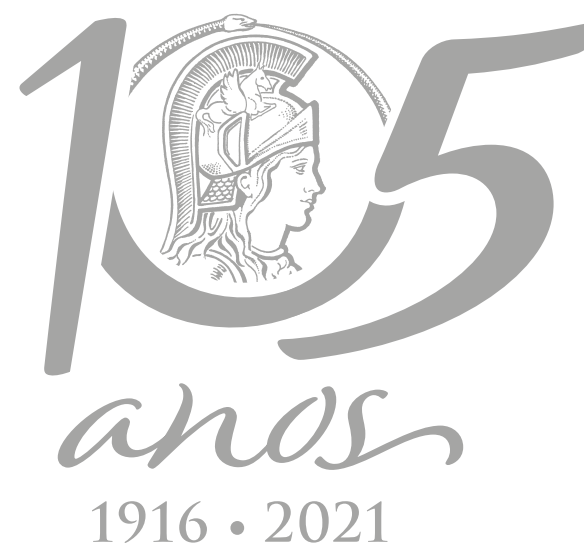

\title{
Ureaplasma diversum clearance in lung mice infection is mediated by neutrophils
}

\author{
JAMILE R. DA SILVA, PERCÍLLIA V.S. DE OLIVEIRA, PATRICIA NOLASCO, HUGO \\ SANTANA, IZADORA S. REZENDE, DENISAR P. DOS SANTOS, JORGE TIMENETSKY, \\ LUCAS M. MARQUES, TIANA B. FIGUEIREDO \& ROBSON A.A DA SILVA
}

\begin{abstract}
Pneumonia in cattle is one of the causes of morbidity rates and economic loss. The host response to lung infections caused by Ureaplasma diversum in bovines is virtually unknown. Here in the immune response was evaluated in a murine model for an experimental pulmonary infection by $U$. diversum. Therefore, AJ, BALB/C and C57BL/ 6 mice received intratracheal inoculation of $U$. diversum and were evaluated after 1, 2, 3, 7 and 14 days and the clinical specimens were collected. In bronchoalveolar lavages (BAL) an increase of inflammatory cells was observed. Neutrophils were the main cells recruited to the site of infection and the infiltration was coincided with the production of pro-inflammatory cytokines. We found a large amount of neutrophil in this initial period, followed by a decrease 7 and 14 days post infection, accompanied by bacterial clearance. Our results evidenced the presence of $U$. diversum within the neutrophil that suggests a phagocytic role of this cell in the elimination of the infection. The immune response features reported here are the initial evidence that healthy immune systems may control these microorganisms. This may be the first step to design new strategies immune based to control the infections in naturally infected hosts.
\end{abstract}

Key words: infection pulmonary, neutrophil, mycoplasma, cattles.

\section{INTRODUCTION}

Bloodstream circulating neutrophils have a short-life and are important in initiating defenses against foreign microorganisms (Summers et al. 2010). After an infection or inflammation, these cells are attracted by mediators, such as complement fragment C5a (Dragomir et al. 2012), leukotriene $B_{4}$ (Afonso et al. 2012), CXCL2 (Uchida et al. 2009), myeloperoxidase (Klinke et al. 2011) and antimicrobial peptides (Ma et al. 2012). These cells migrate and interact with the stimulated endothelial cell surface (Rigby \& DeLeo 2012). Inside the tissues, granules and antimicrobial proteins of mobilized neutrophils kill the infectious agent, but also cause damage to the infected tissue site (Summers et al. 2010).
Usually, the microorganism is destroyed in the phagocytic vacuole of activated neutrophil (Rigby \& DeLeo 2012).

Neutrophils may also be involved in the response to $U$. diversum infections in bovines. This mollicute adheres to the mucosa of the reproductive tract of these animals and may cause important economic loss due to abortion, vulvovaginitis and other urogenital disturbances (ter Laak et al. 1993, Rottem 2003, Petit et al. 2008). Importantly, respiratory infections are common as well and pulmonary diseases might be associate with pneumonia and economic implications. As with all Mollicutes, U. diversum lacks a cell wall but may present an external glycocalix (Marques et al. 2016, Marques et al. 
2010). Like other ureaplasmas, U. diversum hydrolyzes the urea and releases ammonia, intoxicating the host tissue (Glass et al. 2000).

Even after five decades of isolation (TaylorRobinson et al. 1967), there is a little information about this organism and the immune response against $U$. diversum in cattle or other hosts. The mechanisms by which this organism exerts its virulence and pathogenicity are mostly unknown (Amorim et al. 2014, Kim et al. 1994, Marques et al. 2010, Silva et al. 2016).

Despite the description of causal associations, the relationship between $U$. diversum and disorders in its hosts remains controversial. Bovines may show different genetic backgrounds and distinct patterns of immune response to pathogens. This suggests that the interaction pathogen-host is one of the main factors involved in the development of pneumonia in calves.

In this context, a large number of species of mycoplasma have been isolated from the respiratory tract of calves. The three most important species, based on studies of occurrence and pathogenicity, are Mycoplasma bovis, M. dispar, and Ureaplasma sp. In the literature, authors report that ureaplasmal virulence factors include IgA protease, urease, phospholipases $A$ and $C$, and production of hydrogen peroxide (Gourlay \& Howard 1982, Viscardi \& Hasday 2009, Howard 1983). These factors may allow the organism to evade mucosal immune defenses by degrading IgA, and injuring mucosal cells through the local generation of ammonia, membrane phospholipid degradation and prostaglandin synthesis, and membrane peroxidation, respectively (Viscardi \& Hasday 2009, Xiao et al. 2014). However, murine models for the study of inflammation caused by Ureaplasma diversum are very rare in the literature.
We aimed to mimic the different types of immune responses that could occur in natural hosts using different inbred mice strains which ones have divergent immune response patterns as result of genetic mutations and polymorphisms. Although common inbred mice are considered "immune competent," many have variations in their immune system that may affect the phenotype.

Thus, inbred mice become an excellent model to investigate how hosts genetic variability influence immune response in different sort of infections. The knowledge about immune response may help clarify factors underlying $U$. diversum infection. However, there is no experimental model to study pulmonary infections by this mollicute. Here we investigate the initial immune response during an experimental lung infection by $U$. diversum in three different mice strains.

\section{MATERIALS AND METHODS}

\section{Mice}

$\mathrm{BALB} / \mathrm{C}, \mathrm{A} / \mathrm{J}$ and $\mathrm{C} 57 \mathrm{BL} / 6$ mice, age 6 to 8 weeks were obtained from the animal facility of Universidade Federal da Bahia - Instituto Multidisciplinar em Saúde - Campus Anísio Teixeira). Mice were housed in a controlled environment with free access to food and water. The experimental protocol was approved by the Institutional Animal Care and Use Committee of Universidade Estadual de Feira de Santana (UEFS).

\section{Bacterial strain and culture}

U. diversum ATCC 49782 was obtained from the collection of Mycoplasma Laboratory, Institute of Biomedical Sciences at University of São Paulo/ Brazil. U. diversum was cultured in ureaplasma medium (UB) according to Ruhnke \& Rosendal procedures. In a logarithmic growth phase, 
the culture was centrifuged at 15,000 $\times \mathrm{g}$ for 25 minutes at $4^{\circ} \mathrm{C}$, pelleted and gently washed with Phosphate-buffered saline (PBS). The final pellet was homogenized in PBS aliquoted in $1 \mathrm{~mL}$ vials. This inoculum was quantified in 96-well microplates for Determination of Color Changing Units-methodology $(\mathrm{CCU} / \mathrm{mL})$ as described by Kim et al. (1994). For some experiments $U$. diversum was homogenized in PBS and incubated with carbocyanine dye solution (Vybrant ${ }^{\mathrm{TM}}$ Dil cell-labeling solutionDil, V-22885, Molecular Probe, Eugene, Oregon, USA). The viable or inactivated by heat $\left(100^{\circ} \mathrm{C}\right.$ for 30 minutes) bacterial strain was analyzed by flow cytometry. The inactivation was confirmed by absence of a positive culture on UB medium. Negative controls without bacteria inoculation were also used.

\section{Lung infection}

Prior to intratracheal inoculation, mice $(n=6)$ were anesthetized with an intraperitoneal injection of $65 \mathrm{mg} / \mathrm{Kg}$ ketamine and $10 \mathrm{mg} / \mathrm{Kg}$ xylazine. For experiments with unlabeled Ureaplasma each mouse was inoculated intratracheally with $10^{4} \mathrm{CCU} / \mathrm{mL}$ of $U$. diversum by instilling the inoculum into the posterior pharynx of an anesthetized mouse while it was suspended in a vertical position and prevented from swallowing by gentle extension of the tongue. Control mice received saline alone. The mice were maintained in this position until aspiration was witnessed (disappearance of inoculum from the posterior pharynx and retraction of the chest wall) (Viscardi et al. 2002a). The animals were euthanized 1, 2, 3, 7 and 14 days postinoculation for bronchoalveolar lavage and analysis of lung tissue for Ureaplasma by culture and PCR. Additional groups of five mice (BALB/c strain) were infected with $10^{4} \mathrm{CCU} / \mathrm{mL}$ of labeled viable and non-viable $U$. diversum, following the same procedures described above.

\section{Bronchoalveolar lavage}

After euthanasia, bronchoalveolar lavage (BAL) was performed in situ. The trachea was cannulated (21 GA Insyte, Becton Dickinson), and $1 \mathrm{~mL}$ of PBS was infused intratracheally and withdrawn, followed by instillation and recovery of PBS. This procedure was repeated three times. The BAL fluids were stored at $4^{\circ} \mathrm{C}$ until cells were collected by centrifugation at $300 \times \mathrm{g}$ for 10 minutes. Cell-free supernatants were stored at -80 - $\mathrm{C}$ for analysis of cytokine concentrations. Total-cell counts were performed manually with a hemacytometer. Differential cell counts were performed on cytoslides prepared using a cytocentrifuge stained with panoptic according to the manufacturer's instructions. The analysis was performed by two blinded observers using morphological criteria.

\section{Cytokine ELISA}

Concentrations of TNF- $\alpha, I L-1 \beta, I F N-\gamma$ and IL-10 in BAL supernatants were measured by sandwich ELISA (Ready-SET-GO ${ }^{\oplus}$ kit-Bioscience) according to the manufacturer's recommendation.

\section{Lung culture}

To confirm the infection in our model, after euthanasia the mice lungs were removed and processed for Ureaplasma culture and PCR. Following lavage, the lungs were homogenized in $1 \mathrm{~mL}$ of PBS and centrifuged at $300 \times \mathrm{g}$ for 10 minutes at $4^{\circ} \mathrm{C}$. The supernatant (200uL) was added in $1 \mathrm{~mL}$ of UB medium and e incubated at $37^{\circ} \mathrm{C}$ in $95 \%$ air- $5 \% \mathrm{CO}_{2}$. The tubes were examined daily for two weeks for color change.

\section{Polymerase chain reaction (PCR)}

DNA was extracted from lung supernatants by boiling method (Fan et al. 1995) to detect U. diversum. The PCR methodology was performed as described by Cardoso \& colleagues (2000). The DNA of the $U$. divsersum ATCC was the 
positive control and the negative control was an aliquot of PCR mix. The PCR products were electrophoresed in 1.5\% agarose gel, stained with ethidium bromide. A DNA product band of 216 bp visualized by UV illumination was considered positive.

\section{Flow cytometry}

The BAL fluids were collected 24 hours after the infection with labeled U. diversum. Cells were suspended in MACS buffer (PBS, 0.5\% bovine serum albumin, 2 mM EDTA) and surface stained with anti-CD11b and anti-Gr-1 according to the manufacture's protocols. The neutrophil population was selected at the double-positive gateway for CD11b and GR-1. Other non-neutrophil cells were defined for the positive gate in CD11b and negative for GR-1. The buffers and antibodies were purchased from BD Biosciences (CA, USA). The cells were examined by flow cytometry using FACS Fortessa (BD Biosciences San Jose, CA/ USA) and data were analyzed using the Flowlo software (TreeStar, OR, USA). Data are shown as median fluorescence intensity (MFI).

\section{Statistical analysis}

All data are represented as means \pm standard errors (SE). Statistical analysis was performed by multiple comparisons in the different experiments using the test non-parametric (one-way ANOVA) Kruskal-Wallis. Statistical differences were considered significant when $p<0.05$ using a confidence interval of 95\%. Analyzes were performed at GraphPad Prism 4.0 program (GraphPad Software, San Diego, CA, USA). The obtained results were analyzed using Mann Whitney Test. Analyses were performed using GraphPad Prism ${ }^{\circledR}$ software (version 5.0, GraphPad Software, San Diego, CA, USA). Statistical differences were considered significant at $p$ values $<0.05$.

\section{RESULTS}

\section{U. diversum infection induces influx of neutrophils into the lungs}

To assess the immune response after pulmonary infection by $U$. diversum, inbred mice strains $\mathrm{BALB} / \mathrm{C}, \mathrm{A} / \mathrm{J}$ and $\mathrm{C} 57 \mathrm{BL} / 6$ were infected and BAL were collected after 1, 2, 3, 7 and 14 days after infection. $U$. diversum induced a significant recruitment of cells to the site of infection; total BAL cell counts were higher at 1,2 and 3 days postinoculation (Fig. 1). Peaks of BAL cell accumulation occurred at 24 hours in BALB/C and $\mathrm{A} / \mathrm{J}$ lineage while $\mathrm{C} 57 \mathrm{BL} / 6$ reached highest cell count at 48 hours in Ureaplasma-inoculated mice vs. in saline-inoculated controls. After 7 days, we observed a rescue in total BAL cells number to the control levels in all mouse lineages evaluated. It was maintained up to 14 days after infection (Fig. 1).

In order to investigate the cell types that were present in the BAL, we performed differential cell count. The BAL cellular profile of mice that remained healthy during the length of the experiment consisted mainly of macrophages. However, Ureaplasma inoculation stimulated significant changes in BAL cell composition characterized by an influx of neutrophils (Fig. 2). BALB/C and A / / mice showed an intense neutrophil infiltration during the first 72 hours (15 and 40-fold-higher numbers of neutrophils in Ureaplasma-inoculated mice than controls - Fig. $2 \mathrm{a}, \mathrm{b}, \mathrm{c}, \mathrm{d}$ ) with a peak at 24 hours post infection. While C57BL/6 mice showed an increase in the number of neutrophils into the lungs within 48 hours (Fig. 2e, f). There were a decrease in BAL neutrophils content of Ureaplasma-inoculated mice, 7 and 14 days postinoculation with levels similar to the control group (Fig. 2). 

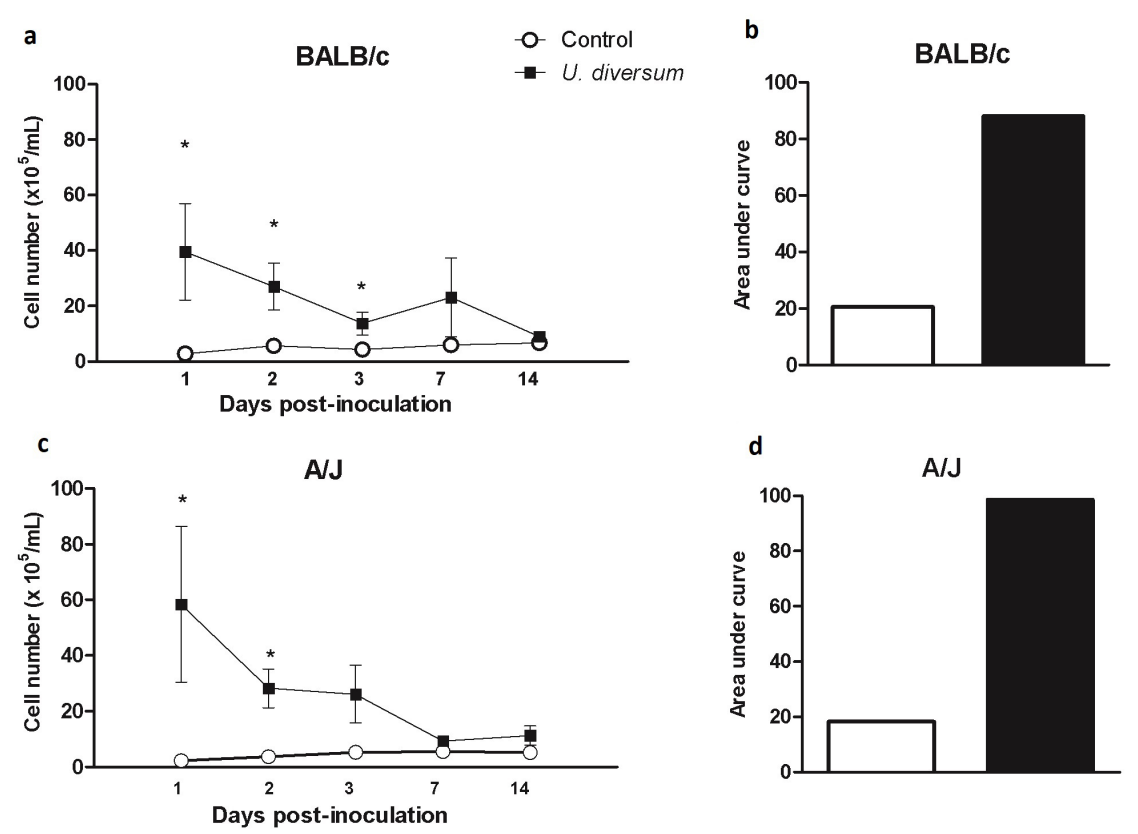

e

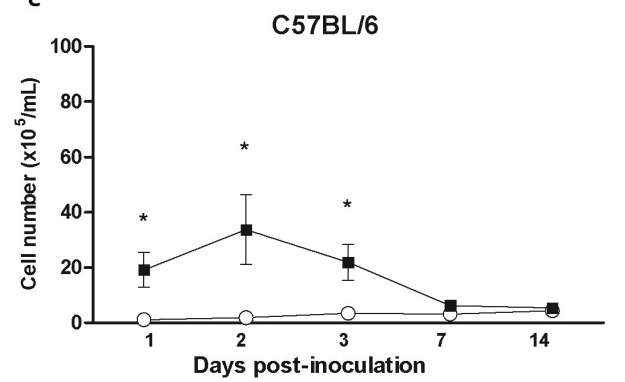

\section{U. diversum-infected lungs stimulates production of pro-inflammatory cytokines}

since we observed the influx of inflammatory cells into the Ureplasma-inoculated mice lungs, we next investigated the cytokines profile present in the BAL fluids of these animals. Analysis of BAL cytokines composition showed an increase of pro-inflammatory profile after infection. $\mathrm{BALB} / \mathrm{C}$ and $\mathrm{A} / \mathrm{J}$ Ureaplasma-inoculated mice showed higher production of IL-1 $\beta$ and TNF- $\alpha$ one-day postinoculation in their BALs (Fig. 3a, b). In contrast, we did not observe any difference in concentration of these cytokines in C57BL/6 mice at the same time postinoculation. These ones showed an increase of IFN- $y$ at the first 48 hours after infection as well as A/J mice (Fig. 3c).
There were no differences between Ureaplasmainoculated mice and saline-inoculated mice after 24 hours in any lineages evaluated when we accessed the anti-inflammatory cytokine IL10 (Fig. 3d).

\section{U. diversum clearance is mediated by neutrophil}

The infection by $U$. diversum was evaluated by culture of lung tissue and PCR. Culture from lungs tissues confirmed the presence of U. diversum in $100 \%$ of inoculated BALB/c all over the period analyzed. C57BL/6 inoculated mice showed positive culture in 100\% one-day after inoculation, while A/J mice showed $66.6 \%$. After 3 days, $66.6 \%$ of cultures were positive in 
a

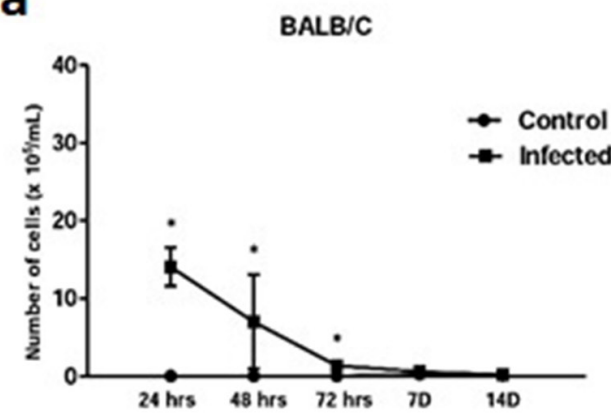

b

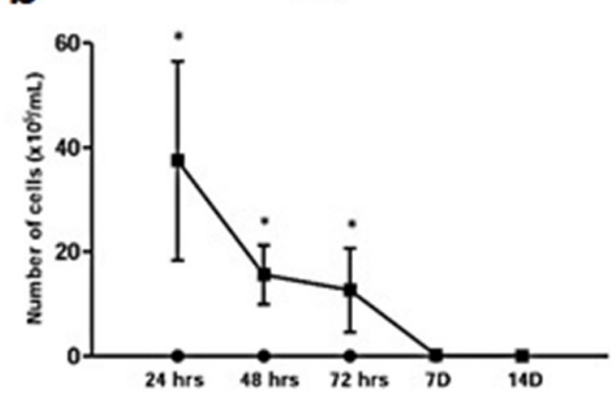

C

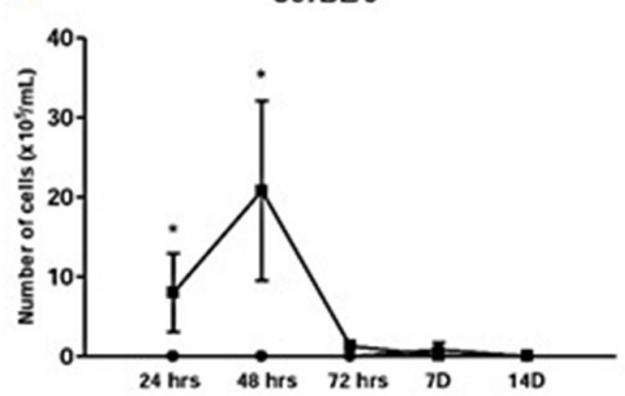

d

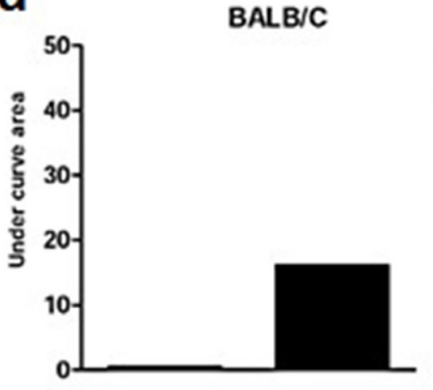

AJ

e

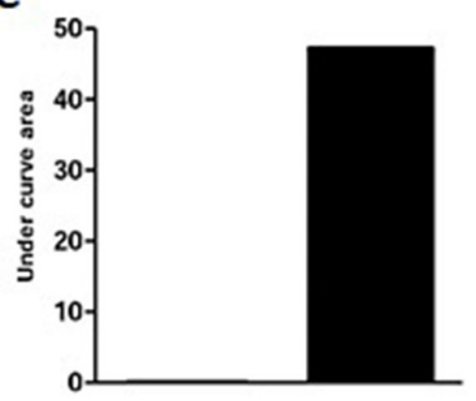

f

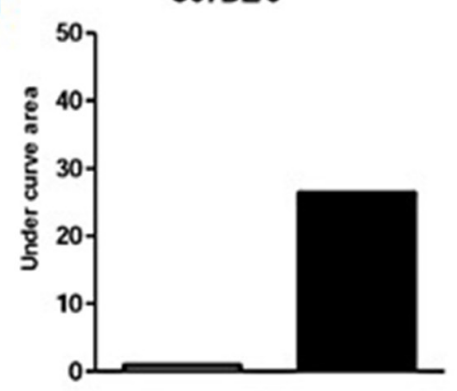

Figure 2.

Neutrophil cell counts in

BAL. Animals were infected intratracheally by $10^{4} \mathrm{CCU}$ of $U$. diversum and euthanized 24, 48,72 hours, 7 and 14 days after infection. The BALs were centrifuged and the pellet resuspended in saline solution. The obtained cytospin slides were stained with Panotic and evaluated by light microscopy. Figures $\mathbf{a}, \mathbf{b}$ and $c$, show the neutrophil numbers in the different times of infection. (a). Balb/C, (b). A/J, (c). C57BL/6 respectively. (d), (e), (f), show area under the curve. $n=6 .{ }^{*} p<0.05$. these both lineages. Samples in culture were considered positive by observation of color changed in UB medium due to alkalization, which is a feature exclusive to Ureaplasmas (not to other mycoplasmas species) since they have urease activity generating an electrochemical gradient through accumulation of ammonia/ ammonium (Fig. 4a). All tissues from noninoculated animals were culture negative.

In parallel, $U$. diversum was detected in lung tissue by PCR as well. We have shown the presence of Ureaplasma in BALB/c mice by positive PCR in all animals analyzed 1, 2, or 3 days postinoculation. In $\mathrm{A} / \mathrm{J}$ and $\mathrm{C57BL} / 6$ lineages, all mice were positive one-day after inoculation, while the percentage of positive animals decreased to $66.6 \% 3$ days post infection. These data suggest that $\mathrm{C} 57 \mathrm{BL} / 6$ followed by $A / J$ tend to control infection faster than BALB/c mice. Moreover, Ureaplasma DNA was not detected by PCR in all animals evaluated 7 and 14 days post infection (Fig. 4b). All lungs of 

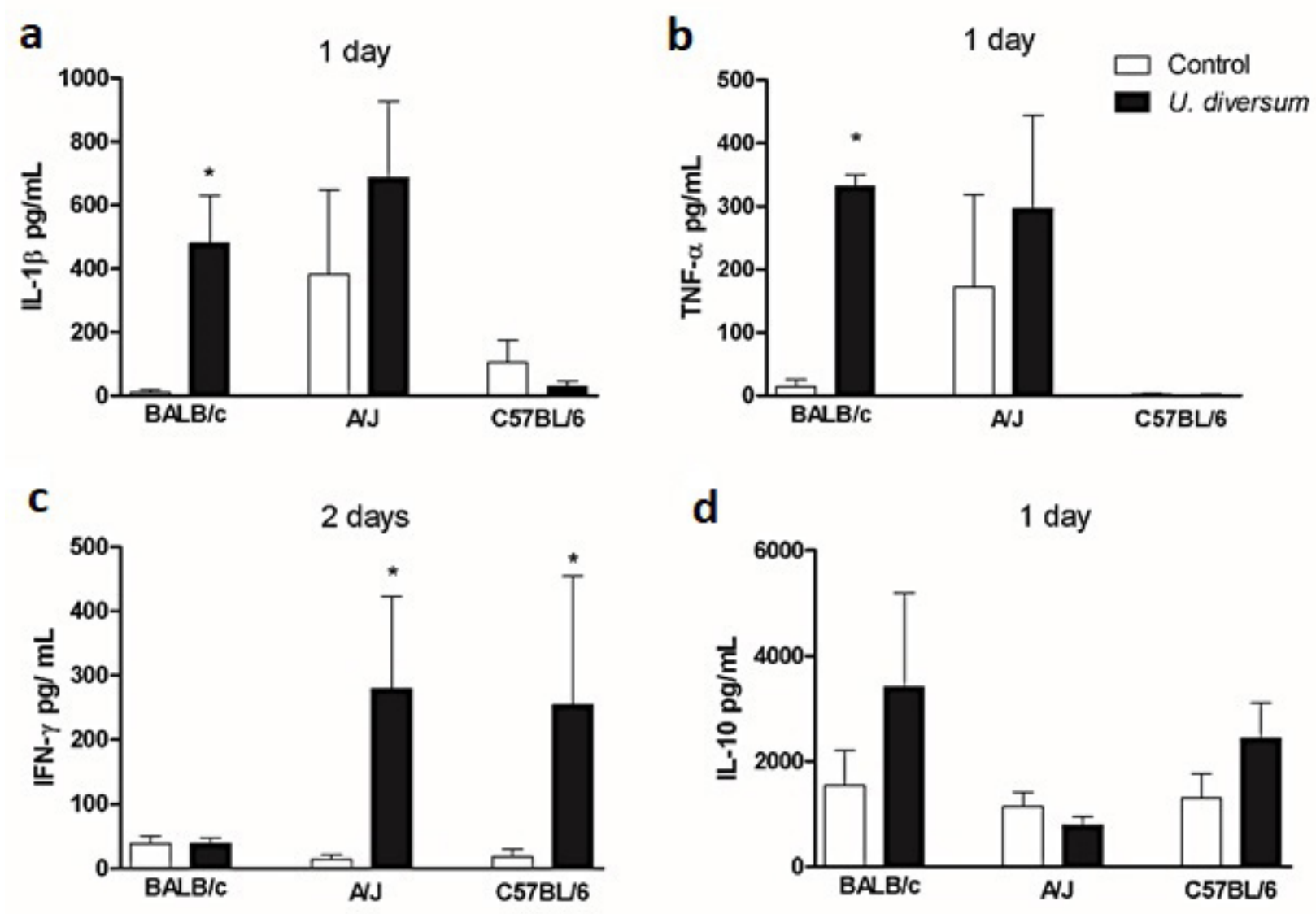

Figure 3. Pulmonary response cytokines. Mice were infected intratracheally by $10^{4} \mathrm{CCU}$ of $U$. diversum and euthanized 1 or 2 days after infection. The BALs were centrifuged and the supernatant of BALs were used for measurement of cytokines (IL-1 $\beta$, TNF- $\alpha$, IFN- $\gamma$ and IL-10) by ELISA. (a) IL1- $\beta$; (b) TNF- $\alpha$; (c) INF-v; (d) IL-10.

saline-inoculated mice were PCR negative. The histology of lungs in infected mice showed an inflammatory infiltrate, unlike the non-infected mice. The infiltrate was more intense one-day postinoculation, but we did not observe severe pulmonary injury. However, in our model, none Ureaplasma-inoculated mice appeared ill and there was no mortality in any lineage evaluated.

Additionally, we assessed the correlation between neutrophils recruitment and the bacterial clearance into the lungs in Ureaplasma-inoculated mice. We hypothesize that the neutrophils influx into the lungs after infection promotes $U$. diversum phagocytosis and triggers bacterial clearance. To confirm this hypothesis, we used labeled U. diversum viable and inactivated by heat. Flow cytometry revealed that fluorescence emission of $U$. diversum strains (viable and inactivated) was present in neutrophils (CD11 $\mathrm{b}^{+} / \mathrm{Gr}-1^{+}$cells) postinoculation, on the other hand, there was no significant fluorescence for $U$. diversum in CD11 $\mathrm{b}^{+} / \mathrm{Gr}-1^{-}$(nonneutrophils population), indicating the presence of Ureaplasma inside neutrophils (Fig. 5a, b and

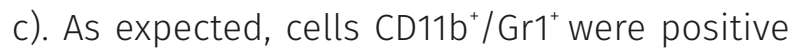
for either viable or inactivated $U$. diversum strain (Fig. 5). Together these data indicate that $U$. diversum is internalized by neutrophils and this process might not be mediated by bacterial invasion. 
a

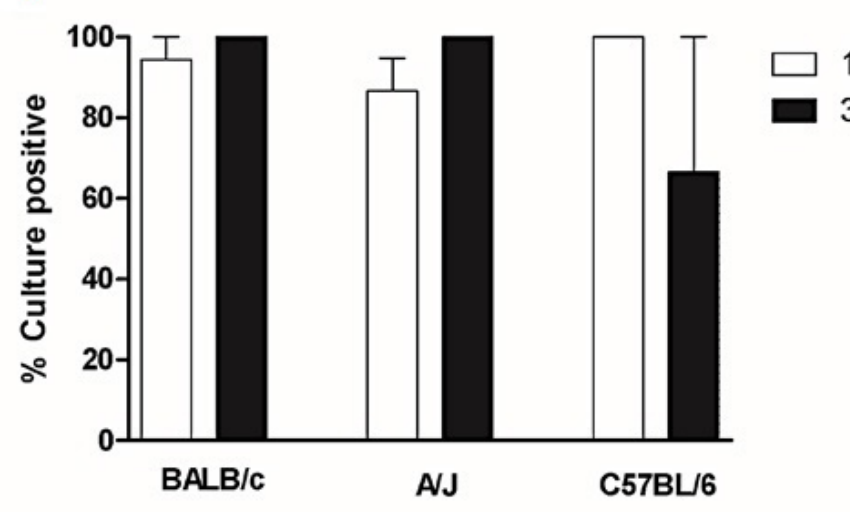

b

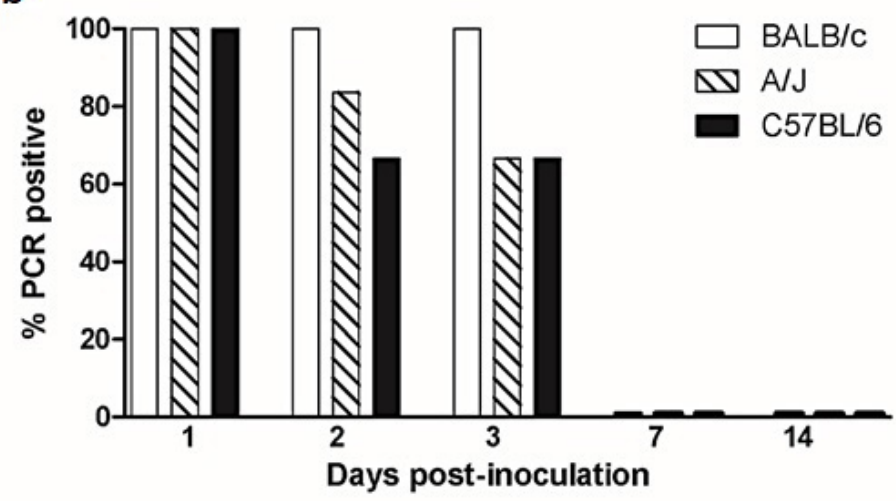

Figure 4. Lung detection of $U$. diversum. (a) The percentage 1 day of cultures in which there was 3 days a color change in the medium ureaplasma recovered from lungs of infected mice 1 and 2 hours post infection. It was considered positive culture, one that showed color change without turbidity, precipitation or any evidence of contamination. (b) Percent of ureaplasmal detecting DNA in infected lung 1, 2, 3, 7 and 14 days post infection by $U$. diversum. Mice of the control groups were negative for both culture and for PCR. $n=6$. a

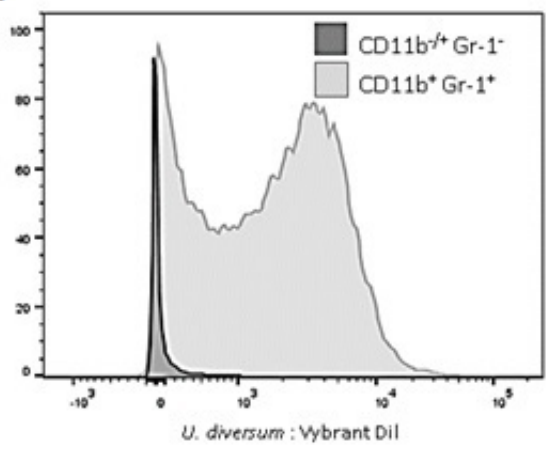

C

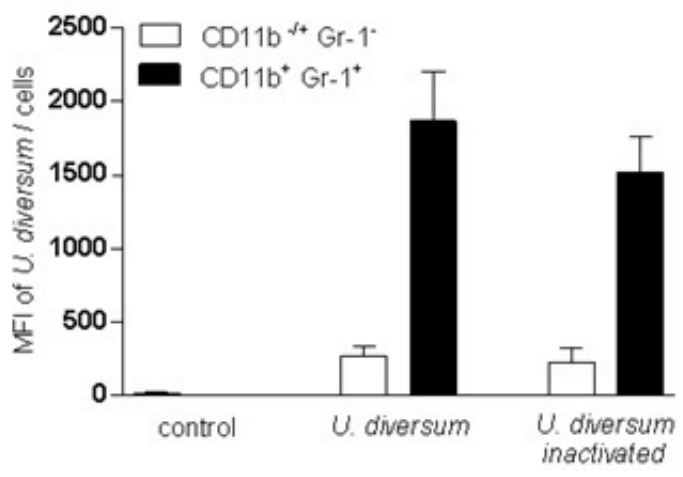

b

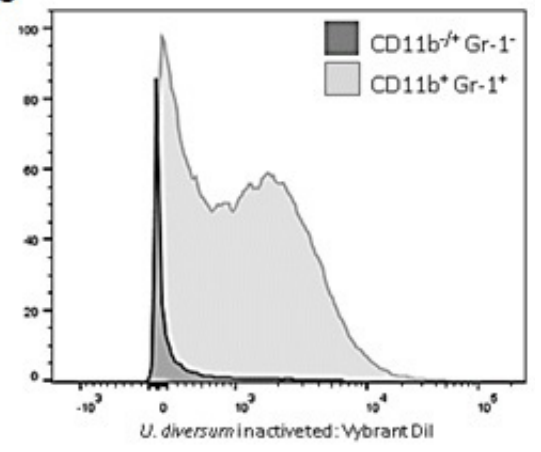
intensity (MFI) was measured on gate neutrophil (CD11b+l GR-1+) and non-neutrophil cells (CD11b+/ Gr-1-). $\mathbf{n}=5$. ${ }^{*} p<0.05$.

Figure 5. Neutrophil mediated $U$. diversum clearance into the lungs. BALB/c were infected intratracheally with $10^{4}$ CCU U. diversum viable or inactivated, labed with vybrant. One day after infection, BAL cells were labeled for anti-CD11B-BV421 and anti-GR1-FITC. The mean vibrant dil fluorescence 


\section{DISCUSSION}

We have shown in this study that pulmonary infection by $U$. diversum in three different mice lineages (BALB/C, A/J and C57BL/6) induced an early influx of cells into the airways and lung tissue, 1 to 3 days after infection. We found a large amount of neutrophil in this initial period, followed by a decrease 7 and 14 days post infection. It was correlated with the absence of Ureaplasma in lung tissue and an increase in pro inflammatory cytokines levels. Our findings suggest that there is a role of neutrophils in the clearance of $U$. diversum, which seems to have contributed to eliminate the infection in all tested lineages. These results provide evidence that the innate immunity may have an important role against of $U$. diversum. Here we demonstrated for the first time, the induction of a protective immune response in the host airways during $U$. diversum infection in a murine model.

$U$. diversum pulmonary infection induced an early influx of neutrophil into the airways and lung tissue after infection. Our experimental model the infection was characterized by an acute inflammation (days 1 to 3 ) and after that a resolution phase (days 7 to 14). Some studies have demonstrated that ureaplasmas can induce a systemic inflammatory response with elevated peripheral leukocyte counts, mainly neutrophils, in neonates with Ureaplasma isolated from the lower respiratory tract (Ohlsson et al. 1993, Ollikainen et al. 1998, Panero et al. 1995). In addition, acute inflammation in Ureaplasmainoculated mice preserved histologic integrity of the lung parenchyma (data not show). However, in other species, for example, Ureaplasma parvum, pneumonic infection in non-human primate models showed that an established infection in the lung leads to inflammation and lung damage by a robust inflammatory infiltrate (Novy et al. 2009). These data suggest that the response generated in our model may be enough to control infection without signal of exacerbation that could compromise the infection site.

An important result of our study was the presence of neutrophils, representing the majority of cells, recruited to the lungs of infected mice. In fact, this data corroborates with others studies showing that infection with Ureaplasma urealyticum induces an early influx of neutrophils into the lung (Viscardi et al. 2002a). In addition, the clearance of infection by Mycoplasma pneumoniae in mice correlates with the presence of polymorphonuclear (Martin et al. 2001, Parker et al. 1987). Indeed, the resolution phase, characterized in that decreased number of neutrophils recruited at 7 and 14 days after infection coincided with the absence of Ureaplasma in lung tissue, suggesting a role of neutrophils in the clearance of infection by $U$. diversum. Furthermore, these data are in accordance with the fact that the rapid attraction of leukocytes to the lungs and subsequent production of pro-inflammatory mediators are necessary for effectively eliminate the infectious agent in mycoplasma infections (Wu et al. 2007).

Additionally, we observed an increase in the pro-inflammatory cytokines levels, such as IL-1 $\beta$, IL-6 and TNF- $\alpha 24$ hours after infection, as well as the production of IFN-y at 48 hours. This same response profile was also observed in vitro when cultures of peritoneal macrophages stimulated by $U$. diversum were able to induce the production of pro-inflammatory cytokines (Chelmonska-Soyta et al. 1994). Our findings in murine models are in agreement with other studies, which have shown that ureaplasmal infection of the respiratory tract promotes a proinflammatory cytokine cascade in the lower respiratory tract. Neonatal Ureaplasma 
infection is consistently associated with increases in TNF- $\alpha, I L-1 \beta$, and IL-8 (De Dooy et al. 2001, Viscardi et al. 2002b). The dynamics of the inflammatory process is characterized by an innate immune response and involves the expression of inflammatory genes such as those that are responsible for coordinated cytokine secretion through activation receptors such as the family of Toll Like Receptor (TLR) (Xiang \& Fan 2010). The activation mechanisms induced by $U$. diversum involving TLRs are not described in the literature. It is known that the infection of BALB/C and C57BL/ 6 mice by $U$. parvum involves the activation of TLR2 (Allam et al. 2014). Furthermore, the antigen lipoprotein exposed on the surface of the membrane and shared between the species of $U$. urealyticum and U. parvum interact with TLR2 and TLR4 activating NF-kB, which is involved in signaling to increase production of inflammatory cytokines (Peltier et al. 2007, Triantafilou et al. 2013). The production of IFN-y suggests the involvement of TLRs receptors, which may be capable of inducing signaling pathways that culminate in the activation of expression of interferons (Bourgeois \& Kuchler 2012). In the literature, authors have reported that they are capable of promoting a significant inflammatory response by activation of Toll Like Receptor 2 (TLR2), indicating that surface molecules are important for the activation of inflammatory response (Marques et al. 2016).

We assessed $U$. diversum infection in cultured lungs to confirm the infection within 24 to 72 hours and monitored by PCR. Among strains, C57BL/ 6 tends to control the infection faster than other strains. This is in agreement with the literature which demonstrates BALB/C mice more susceptible to Ureaplasma infections (von Chamier et al. 2012). Comparing the data, among the three strains recruitment of neutrophils was higher in A/J mice. The largest population of neutrophils present in this strain together with the production of cytokines may explain the differences obtained in PCRS from $A / J$ and BALB/C. In this way, the genetic background of the animals and pathogen virulence factors may be responsible for modulating the pro-inflammatory response mediated by inflammatory cells involved in the control of infection by $U$. diversum. Here, all mouse lineages eliminate the infection after 7 days.

The results show that neutrophils are able to phagocyte $U$. diversum, performing the depuration of the microorganism. Exploration of the mechanisms involved in the interaction pathogen/host in different strains of mice may be useful in developing immune based strategies to control infections caused by mycoplasmas in bovines. Historically, these studies have been difficulties because of logistical and economic challenges of working with the natural host and the inability to successfully create a laboratory animal model that reproduce clinic signs observed in cattle.

Virulence factors of the $U$. diversum related to activation and stimulation of the host immune system remain unclear. Here we showed the first report of participation of neutrophils in the control of $U$. diversum. Neutrophils are the first cells to migrate to the sites of infection and play important roles in defense against $U$. diversum. The role of neutrophils involves phagocytosis, in addition to the production of cytokines, capable of activating other cells involved in the elimination of the pathogen (Fig. 6).

The immune response features reported here are the initial evidence that healthy immune systems may control these microorganisms. This may be the first step to design new strategies immune based to control the infections caused by $U$. diversum in naturally infected hosts. 


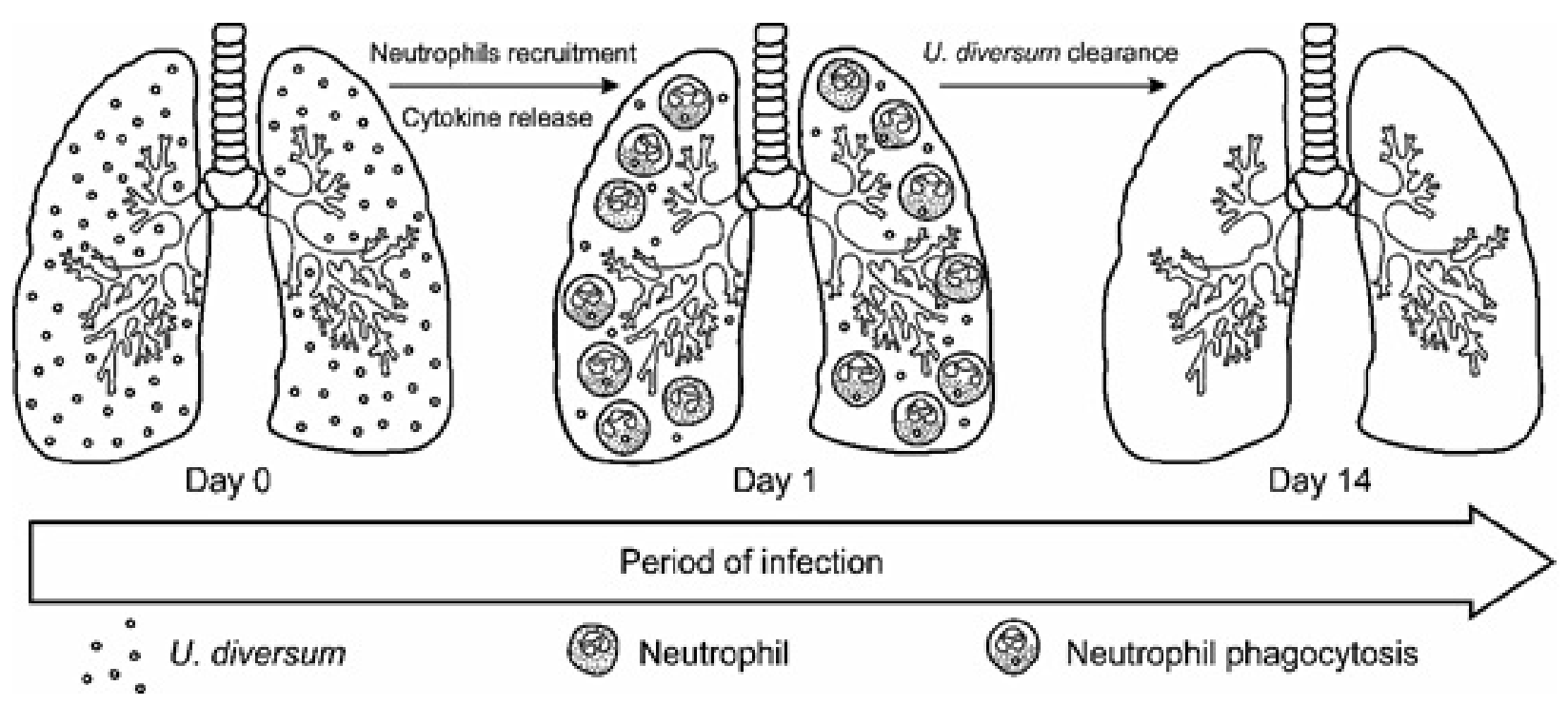

Figure 6. Schematic figure of $U$. diversum clearance. Mice were infected intratracheally by $10^{4} \mathrm{CCU}$ of $U$. diversum and euthanized 1, 2, 3, 7 and 14 days after infection. The results show that neutrophils are able to phagocyte $U$. diversum, performing the depuration of the microorganism and the role of neutrophils involves phagocytosis, in addition to the production of cytokines, capable of activating other cells involved in the elimination of the pathogen.

\section{Acknowledgments}

This study was supported by grants from Fundação de Amparo à Pesquisa do Estado da Bahia (FAPESB/Grant number PPP7368/2009), from PRODOC-UFBA (02/2011), and from University of São Paulo. We thankfully acknowledge the Nicole Klebier for assistance in image editing.

\section{REFERENCES}

AFONSO PV, JANKA-JUNTTILA M, LEE YJ, MCCANN CP, OLIVER CM, AAMER KA, LOSERT W, CICERONE MT \& PARENT CA. 2012. LTB4 is a signal-relay molecule during neutrophil chemotaxis. Dev Cell 22: 1079-1091.

ALLAM AB, VON CHAMIER M, BROWN MB \& REYES L. 2014. Immune profiling of BALB/C and $\mathrm{C} 57 \mathrm{BL} / 6$ mice reveals a correlation between Ureaplasma parvum-Induced fetal inflammatory response syndrome-like pathology and increased placental expression of TLR2 and CD14. Am J Reprod Immunol 71: 241-251.

AMORIM AT ET AL. 2014. Apoptosis in HEp-2 cells infected with Ureaplasma diversum. Biol Res 47: 38.

BOURGEOIS C \& KUCHLER K. 2012. Fungal pathogens-a sweet and sour treat for toll-like receptors. Front Cell Infect Mi 2: 142 .
CARDOSO HFT, SILVA N, SENA MJ \& CARMO. 2000. Production of enterotoxins and toxic shock syndrome toxin by Staphylococcus aureus isolated from bovine mastitis in Brazil. Lett Appl Microbiol 29: 347-349.

CHELMONSKA-SOYTA A, MILLER RB, RUHNKE L \& ROSENDAL S. 1994. Activation of murine macrophages and lymphocytes by Ureaplasma diversum. Can J Vet Res 58: 275-280.

DE DOOY JJ, MAHIEU LM \& VAN BEVER HP. 2001. The role of inflammation in the development of chronic lung disease in neonates. Eur J Pediatr 160: 457-463.

DRAGOMIR CL, SCOTT JL, PERINO G, ADLER R, FEALY S \& GOLDRING MB. 2012. Acute inflammation with induction of anaphylatoxin $\mathrm{C} 5 \mathrm{a}$ and terminal complement complex c5b-9 associated with multiple intra-articular injections of hylan G-F 20: a case report. Osteoarthr Cartil 20: 791-795.

FAN HH, KLEVEN SH \& JACKWOOD MW. 1995. Application of polymerase chain reaction with arbitrary to strain identification of Mycoplasma gallisepticum. Avian Dis 39(4): 729-735.

GLASS J, LEFKOWITZ EJ, GLASS JS, HEINER CR, CHEN EY \& CASSELL GH. 2000. The complete sequence of the mucosal pathogen Ureaplasma urealyticum. Nature 407: 757-762.

GOURLAY RN \& HOWARD CJ. 1982. Respiratory mycoplasmosis. Adv Anim Vet Sci 26: 289-332. 
HOWARD CJ. 1983. Mycoplasmas and bovine respiratory disease: studies related to pathogenicity and the immune response--a selective review. Yale J Biol Med 56: 789-797.

KIM JJ, QUINN PA \& FORTIER MA. 1994. Ureaplasma diversum infection in vitro alters prostaglandin E2 and prostaglandin $\mathrm{F} 2 \mathrm{a}$ production by bovine endometrial cells without affecting cell viability. Infect Immun 62: 1528-1533.

KLINKE A ET AL. 2011. Myeloperoxidase attracts neutrophils by physical forces. Blood 117: 1350-1358.

MA X, CHANG W, ZHANG C, ZHOU X \& YU F. 2012. Staphylococcal Panton-Valentine leukocidin induces pro-inflammatory cytokine production and nuclear factor-kappa B activation in neutrophils. PLoS ONE 7: e34970.

MARQUES LM ET AL. 2016. Ureaplasma diversum Genome Provides New Insights about the Interaction of the Surface Molecules of This Bacterium with the Host. PLoS ONE 11: e0161926.

MARQUES LM ET AL. 2010. Invasion of Ureaplasma diversum in Hep-2 cells. BMC Microbiol 10: 83.

MARTIN RJ, CHU HW, HONOUR JM \& HARBECK RJ. 2001. Airway inflammation and bronchial hyperresponsiveness after Mycoplasma pneumoniae infection in a murine model. Am J Respir Cell Mol Biol 24: 577-582.

NOVY MJ, DUFFY L, AXTHELM MK, SADOWSKY DW, WITKIN SS, GRAVETT MG, CASSELL GH \& WAITES KB. 2009. Ureaplasma parvum or Mycoplasma hominis as sole pathogens cause chorioamnionitis, preterm delivery, and fetal pneumonia in rhesus macaques. Reprod Sci 16: 56-70.

OHLSSON A, WANG E \& VEARNCOMBE M. 1993. Leukocyte counts and colonization with Ureaplasma urealyticum in preterm neonates. Clinical infectious diseases: an official publication of the Infec Dis Soci of A 17(Suppl 1): S144-147.

OLLIKAINEN J, HEISKANEN-KOSMA T, KORPPI M, KATILA ML \& HEINONEN K. 1998. Clinical relevance of Ureaplasma urealyticum colonization in preterm infants. Acta Paediatr 87: 1075-1078.

PANERO A, PACIFICO L, ROSSI N, ROGGINI M \& CHIESA C. 1995. Ureaplasma urealyticum as a cause of pneumonia in preterm infants: analysis of the white cell response. Arch Dis Child Fetal Neonatal Ed 73: F37-40.

PARKER RF, DAVIS JK, BLALOCK DK, THORP RB, SIMECKA JW \& CASSELL GH. 1987. Pulmonary clearance of Mycoplasma pulmonis in $\mathrm{C} 57 \mathrm{BL} / 6 \mathrm{~N}$ and $\mathrm{C} 3 \mathrm{H} / \mathrm{HeN}$ mice. Infect Immun 55: 2631-2635.
PELTIER MR, FREEMAN AJ, MU HH \& COLE BC. 2007. Characterization of the macrophage-stimulating activity from Ureaplasma urealyticum. Am J Reprod Immunol 57: 186-192.

PETIT T, SPERGSER J, AURICH J \& ROSENGARTEN R. 2008. Prevalence of Chlamydiaceae and Mollicutes on the genital mucosa and serological findings in dairy cattle. Vet Microbiol 127: 325-333.

RIGBY KM \& DELEO FR. 2012. Neutrophils in innate host defense against Staphylococcus aureus infections. Semin Immunol 34: 237-259.

ROTTEM S. 2003. Interaction of mycoplasmas with host cells. Physiol Ver 83: 417-432.

SILVA JR, FERREIRA LF, OLIVEIRA PV, NUNES IV, PEREIRA IS, TIMENETSKY J, MARQUES LM, FIGUEIREDO TB \& SILVA RA. 2016. Intra-uterine experimental infection by Ureaplasma diversum induces TNF-alpha mediated womb inflammation in mice. An Acad Bras Cienc 88: 643-652.

SUMMERS C, RANKIN SM, CONDLIFFE AM, SINGH N, PETERS AM \& CHILVERS ER. 2010. Neutrophil kinetics in health and disease. Trends Immunol 31: 318-324.

TAYLOR-ROBINSON D, HAIG DA \& WILLIAMS MH. 1967. Bovine T-strain mycoplasma. Ann N Y Acad Sci 143: 517-518.

TER LAAK EA, VAN DIJK JE \& NOORDERGRAAF JH. 1993. Comparison of pathological signs of disease in specificpathogen-free calves after inoculation of the respiratory tract with Ureaplasma diversum or Mycoplasma canis. J Comp Pathol 108: 121-132.

TRIANTAFILOU M, DE GLANVILLE B, ABOKLAISH AF, SPILLER OB, KOTECHA S \& TRIANTAFILOU K. 2013. Synergic activation of toll-like receptor (TLR) $2 / 6$ and 9 in response to Ureaplasma parvum \& urealyticum in human amniotic epithelial cells. PLoS ONE 8: e61199.

UCHIDA Y, FREITAS MC, ZHAO D, BUSUTTIL RW \& KUPIECWEGLINSKI JW. 2009. The inhibition of neutrophil elastase ameliorates mouse liver damage due to ischemia and reperfusion. Liver transplantation: official publication of the AASLD and the International Liver Transplant 15: 939-947.

VISCARDI RM \& HASDAY JD. 2009. Role of Ureaplasma species in neonatal chronic lung disease: epidemiologic and experimental evidence. Pediatr Res 65: 84R-90R.

VISCARDI RM, KAPLAN J, LOVCHIK JC, HE JR, HESTER L, RAO S \& HASDAY JD. 2002a. Characterization of a murine model of Ureaplasma urealyticum pneumonia. Infect Immun 70: 5721-5729. 
VISCARDI RM, MANIMTIM WM, SUN CC, DUFFY L \& CASSELL GH. 2002b. Lung pathology in premature infants with Ureaplasma urealyticum infection. Pediatric and developmental pathology: the official journal of the Society for Pediatr Dev Pathol and the Pediatr Dev Pathol 5: 141-150.

VON CHAMIER M, ALLAM A, BROWN MB, REINHARD MK \& REYES L. 2012. Host genetic background impacts disease outcome during intrauterine infection with Ureaplasma parvum. PLOS ONE 7: e44047.

WU Q, MARTIN RJ, RINO JG, BREED R, TORRES RM \& CHU HW. 2007. IL-23-dependent IL-17 production is essential in neutrophil recruitment and activity in mouse lung defense against respiratory Mycoplasma pneumoniae infection. Microbes Infect 9: 78-86.

XIANG M \& FAN J. 2010. Pattern recognition receptordependent mechanisms of acute lung injury. Mol Med 16: 69-82.

XIAO L, CRABB DM, DAI Y, CHEN Y, WAITES KB \& ATKINSON TP. 2014. Suppression of antimicrobial peptide expression by ureaplasma species. Infect Immun 82: 1657-1665.

\section{How to cite}

SILVA JM, DE OLIVEIRA PVS, NOLASCO P, SANTANA H, REZENDE IS, DOS SANTOS DP, TIMENETSKY J, MARQUES LM, FIGUEIREDO TB \& DA SILVA RAA. 2021. Ureaplasma diversum clearance in lung mice infection is mediated by neutrophils. An Acad Bras Cienc 93: e20200424. DOI 10.1590/00013765202120200424.

Manuscript received on April 2, 2020;

accepted for publication on July 22, 2020

\section{JAMILE R. DA SILVA,}

https://orcid.org/0000-0002-1945-7049

PERCÍLLIA V.S. DE OLIVEIRA ${ }^{1}$

https://orcid.org/0000-0002-9076-9707

\section{PATRICIA NOLASCO 1}

https://orcid.org/0000-0001-8171-2074

\section{HUGO SANTANA ${ }^{1}$}

https://orcid.org/0000-0002-2259-4239

\section{IZADORA S. REZENDE ${ }^{2}$}

https://orcid.org/0000-0001-8699-8534

\section{DENISAR P. DOS SANTOS ${ }^{1,2}$}

https://orcid.org/0000-0002-3930-9510

\section{JORGE TIMENETSKY ${ }^{3}$}

https://orcid.org/0000-0002-1344-3906

\section{LUCAS M. MARQUES ${ }^{1,3}$}

https://orcid.org/0000-0002-8276-8149

TIANA B. FIGUEIREDO ${ }^{1}$

https://orcid.org/0000-0002-5607-9526

\section{ROBSON A.A DA SILVA}

https://orcid.org/0000-0003-1361-1591

${ }^{1}$ Universidade Federal da Bahia, Instituto Multidisciplinar em Saúde - Campus Anísio Teixeira, Rua Hormindo Barros, 58, Candeias, 45029-094 Vitoria da Conquista, BA, Brazil

${ }^{2}$ Centro Universitário FG - UniFG, Departamento de Farmácia, Av. Barão do Rio Branco, 459,

Centro, 46430-000 Guanambi, BA, Brazil

${ }^{3}$ Universidade de São Paulo, Instituto de Ciências Biomédicas, Departamento de Microbiologia, Av. Professor Lineu Prestes, 1374, Cidade Universitária 05508-900 São Paulo, SP, Brazil

${ }^{4}$ Universidade de São Paulo, Departamento de Microbiologia, ICB II, Laboratório de Desenvolvimento de Vacinas, Avenida Prof. Lineu Prestes, 1374, Cidade Universitária, 05508-000 São Paulo, SP, Brazil

Correspondence to: Robson Amaro Augusto da Silva E-mail: robson.amaro@gmail.com

\section{Author contributions}

RAAS conceived the idea. JRS, PVSO, PN, ISR and HS contributed with the interpretation of data, carried out the analysis of the data and the preparation of figures. DPS, JRS and PVSO contributed developing the discussion section and writing the manuscript. All authors are involved in interpreting the results and contributed reviewing the manuscript. RAAS, JT, TBF and LMM supervised the final version. All authors read and approved the final manuscript.

\section{(cc) BY}

